\title{
PERANAN PEMUDA GEREJA DALAM PEMBANGUNAN BANGSA
}

\author{
Jermia Djadi
}

Intisari

Pembangunan bangsa sangat besar ditentukan oleh peran pemuda secara aktif dan kreatif dengan didasarkan atas kualifikasi spiritual, intelektual yang baik, ketahanan, kualitas moral yang terpuji, dan ideologi yang terpuji

\section{Pendahuluan}

Pemuda sering disebut generasi muda, yang merupakan istilah demografis dan sosiologis dalam konteks tertentu. Secara psikologis pemuda adalah orang yang mempunyai jiwa kepemudaan dan identitas kepemudaan. Ada pepatah mengatakan, "Barangsiapa menguasai generasi muda berarti menguasai masa depan bangsa." Ini berarti masa depan bangsa terletak di dalam tangan generasi muda. Generasi mudalah yang harus berperan aktif dalam membangun bangsanya.

Banyak buku ditulis tentang pembinaan terhadap pemuda, tetapi hampir tidak ada buku yang ditulis tentang peranan pemuda gereja. Namun demikian, penulis telah berusaha menyiapkan materi yang berjudul "Peranan Pemuda Gereja Dalam Pembangunan Bangsa," dengan harapan pemuda gereja sebagai warga negara kerajaan Allah dan warga negara Republik Indonesia dapat mengambil peranan dan ikut serta dalam pembangunan bangsa.

Sebelum dikemukakan peranan pemuda gereja dalam pembangunan bangsa, terlebih dahulu akan disampaikan permasalahan bangsa dan kualifikasi pemuda gereja dalam pembangunan bangsa.

\section{Permasalahan Bangsa}

Perlu diketahui bahwa berbagai permasalahan terjadi dalam negara kita hingga saat ini, antara lain:
Pertama, menurunnya jiwa idealisme, patriotisme, dan nasionalisme di kalangan masyarakat Indonesia. Ini terbukti dengan terjadinya disintegrasi bangsa, di mana beberapa provinsi mau memisahkan diri dari kesatuan Republik Indonesia, seperti munculnya Gerakan Aceh Merdeka (GAM), Organisasi Papua Merdeka (OPM), Republik Maluku Selatan (RMS), dan sebagainya.

Kedua, terjadinya berbagai krisis, seperti krisis politik, krisis ekonomi, krisis moneter, dan sebagainya. Salah satu penyebab terjadinya berbagai krisis tersebut karena adanya krisis moral dan krisis kepercayaan. Banyaknya koruptor kelas kakap melakukan korupsi secara terstruktur dan besar-besaran, sehingga negara kita masuk dalam daftar nominasi sebagai negara koruptor dengan peringkat sepuluh besar di dunia. Karena terjadi krisis kepercayaan, para investor asing tidak berani menanamkan modalnya di Indonesia, ditambah lagi adanya ancaman bom bunuh diri dari para teroris yang tidak mengenal prikemanusiaan telah terjadi di beberapa tempat di Indonesia, seperti di Legian Bali, Jakarta, dan sebagainya, yang menyebabkan tidak adanya rasa aman.

Ketiga, hal tersebut di atas menyebabkan kurangnya lapangan kerja atau kesempatan kerja dan tingginya tingkat pengangguran di kalangan masyarakat yang dapat mengakibatkan berkurangnya produktivitas nasional dan memperlambat kecepatan laju perkembangan pembangunan nasional serta dapat menimbulkan berbagai problem sosial lainnya. Banyak 
rakyat Indonesia jatuh miskin. Menurut sumber: PIK, dari 207,44 juta jiwa penduduk Indonesia pada tahun 1999, 138,91 juta jiwa dinyatakan berada di bawah garis kemiskinan. Akibatnya, timbul berbagai tindakan kekerasan dan kejahatan, seperti pencurian, perampokan, dan sebagainya, bahkan banyak rumah tangga terancam cerai.

Keempat, terjadinya masalah lingkungan hidup, seperti perusakan hutan yang mengakibatkan terjadinya bencana alam, seperti banjir dan tanah longsor; terjadinya pencemaran air sungai, danau, dan laut, serta udara karena ulah manusia yang tidak bertanggung jawab.

\section{Kualifikasi Pemuda Gereja Dalam Pembangunan Bangsa}

Untuk mengatasi permasalahan di atas dan membangun bangsa Indonesia, dibutuhkan peranan pemuda gereja yang memiliki kualifikasi berikut ini.

Pertama, pemuda gereja harus memiliki kualitas spiritual yang tinggi. Ketahanan nasional dan kelangsungan pembangunan bangsa hanya dapat stabil dan dinamis jika para pemimpin, khususnya pemuda gereja memiliki ketahanan spiritual yang tinggi. Pemuda gereja sebagai pemimpin yang akan berhasil untuk melanjutkan pembangunan bangsa dalam negara Indonesia, adalah pemuda yang sungguh-sungguh menyadari dan meyakini ketergantungannya kepada anugerah Tuhan semata-mata. Dia tidak akan pudar ditelan sejarah dan tidak patah terkulai dilindas masa, karena pengurapan Roh Kudus dan kuasa firman-Nya menjamin kemandirian kepemimpinannya. Penyalahgunaan ilmu pengetahuan, kerapuhan moral, dan kelumpuhan ideologi hanya mungkin teratasi jika kehidupan para pemuda gereja, termasuk pemimpin dan pemuka masyarakat memiliki ketangguhan moral dan keimanan yang kokoh.
Kedua, pemuda gereja harus memiliki intelektualitas yang mampu bersaing. Abad XXI adalah abad persaingan dan pertarungan antara intelektual manusia. Abad XXI tidak akan memberi tempat bagi pemuda gereja yang hanya mempunyai gelar kehormatan dengan selembar piagam tanpa kreativitas intelektual yang mempunyai daya saing. Alfred North Whitehead pernah mengatakan bahwa ilmu dan agama adalah dua kekuatan raksasa terbesar di dunia yang secara hebat mempengaruhi manusia. Demi panggilan gereja untuk menggarami dunia, maka pemuda gereja yang hidup di abad XXI ini harus berlomba mencari keselarasan antara ilmu pengetahuan dan agama, jika dia tidak ingin dilindas oleh zamannya.

Ketiga, pemuda gereja harus memiliki ketahanan dan kualitas moral yang terpuji. Arus globalisasi yang telah membawa perubahan yang sangat cepat di seluruh dunia, turut mempengaruhi pergeseran nilai-nilai moral etis manusia. Degradasi moral yang melanda seluruh dunia, khususnya di Indonesia bukan saja sebagai produksi zamannya, melainkan juga karena penyalahgunaan atas hak hidup sebagai makhluk sosial yang diberikan oleh Sang Pencipta alam semesta. Kitab suci telah menguak kompleksitas moral yang melanda seluruh dunia pada akhir zaman, termasuk peranan moral abad XXI:

Manusia akan mencintai dirinya sendiri dan menjadi hamba uang. Mereka akan membual dan menyombongkan diri, mereka akan menjadi pemfitnah, mereka akan berontak terhadap orang tua dan tidak tahu berterima kasih, tidak mempedulikan agama, tidak tahu mengasihi, tidak mau berdamai, suka menjelekkan orang, tidak dapat mengekang diri, garang, tidak suka yang baik, suka menghianat, tidak berpikir panjang, berlagak tahu, lebih menuruti hawa nafsu daripada menuruti Allah. Secara lahiriah mereka menjalankan ibadah mereka tetapi 
pada hakikatnya mereka memungkiri kekuatannya (2 Tim. 3:2-5a).

Pernyataan Alkitab ini merupakan gambaran moral manusia secara universal. Egoisme dan legalisme berjalan bersamasama mewarnai moral manusia. Agama yang diyakini sebagai sumber kekuatan moral akan menghadapi tantangan besar. Tetapi justru pada masa ini, ketangguhan iman setiap pemuda gereja akan diuji. Pengaruh penyalahgunaan ilmu pengetahuan dan teknologi akan melahirkan manusia-manusia yang rapuh moral. Ambisi untuk saling menguasai akan membawa rasa tidak aman bagi setiap orang yang gila kekuasaan, sementara para kaum moralis akan semakin tersisih. Namun moralitas yang didasarkan kepada kebenaran hakiki, yakni pemuda gereja yang tetap menghormati panggilannya dan setia dalam pengabdiannya yang tinggi, tidak akan pudar oleh buruknya situasi. Oleh karena itu, pemuda gereja yang menjadi pemuka masyarakat dituntut hadir sebagai panutan moral yang mampu menantang badai zaman. Jika pemuda gereja gagal secara moral, ia akan sangat sulit merehabilitasi namanya di hadapan manusia. Abad XXI bukan saja sebagai tantangan intelektual bagi para ilmuwan, tetapi juga merupakan tantangan moral bagi pemuda gereja dalam membangun bangsa.

Keempat, pemuda gereja harus memiliki ideologi yang teruji. Pemuda gereja akan lebih fungsional dalam bidangnya dalam membangun bangsa, jika disertai kematangan ideologi. Dalam konteks Negara Indonesia yang berdasarkan ideologi Pancasila, semua pola pikir harus berorientasi kepada ideologi Pancasila, demi kepentingan masyarakat Indonesia. Pemuda gereja akan lumpuh secara mental-intelektual jika dasar ideologinya menyimpang dari Pancasila. Kita patut bersyukur sebab Pancasila dan
Undang-Undang Dasar 1945, sudah menjadi fondasi permanen bagi pembangunan bangsa Indonesia dan memberikan kebebasan berpendapat bagi setiap warganya. Sebagai masyarakat Indonesia yang mencintai Negara Indonesia dan Pancasila, pemuda gereja harus menyadari arah ideologinya ke mana dan di mana. Kitalah yang harus menyesuaikan diri dengan Pancasila dan bukan sebaliknya. Dalam perspektif Kristiani, selain menghormati Alkitab sebagai dasar pengajaran dan dasar beriman untuk hidup yang akan datang, pengajaran Kristiani juga sangat menjunjung tinggi nilai Pancasila sebagai dasar ideologi dalam berbangsa dan bernegara. Pancasila senantiasa menghadirkan inspirasi berpikir ideologis dan teologis untuk memahami nilai-nilai yang terkandung di dalamnya. Bagi umat Kristen Indonesia, tidak ada ketegangan antara Pancasila sebagai ideologi dan Alkitab sebagai dasar iman dan teologi Kristen. Masyarakat Kristen di Indonesia menerima Pancasila sebagai dasar ideologi, membuktikan bahwa umat Kristen adalah masyarakat Indonesia yang mencintai negaranya dan sangat peduli terhadap pembangunan bangsa. Pancasila dan iman Kristen adalah dua falsafah yang senantiasa berjalan bersama-sama sebagai tuntutan hidup setiap orang Kristen dalam menunaikan tugas dan panggilannya di masa depan dalam pembangunan nasional dan kerajaan Allah. Dengan demikian, kita tahu sekarang bahwa ideologi Pancasila adalah ideologi pembangunan. Oleh karena itu, pemuda gereja yang lahir pada abad XXI ini, haruslah menjadi pemikir yang mampu berkompetisi untuk pembangunan bangsa dan kerajaan Allah. Pembangunan selalu mengarah ke masa depan. Oleh sebab itu, tidak pada tem-patnya pemuda gereja berpuas diri dengan apa yang sudah dicapai. Pemuda gereja tidak boleh bertanya, "Apa yang negara berikan kepada saya," melainkan harus bertanya, 
"Apa yang dapat saya berikan bagi negara." Dalam membangun bangsa, sangat didambakan pemuda-pemuda gereja yang kreatif, berdedikasi, bermoral terpuji, Pacasilais, dan mampu berkompetitif secara sehat.

\section{Peranan Pemuda Gereja Dalam Pembangunan Bangsa}

Pemuda gereja sebagai warga kerjaan Allah dan warga negara Indonesia mempunyai peranan penting dalam pembangunan bangsa, yaitu membangun manusia seutuhnya dan segala makhluk ciptaan Allah serta lingkungan hidup di bumi Indonesia khususnya. Adapun peranan pemuda gereja dalam pembangunan bangsa adalah sebagai berikut.

Pertama, pemuda gereja memiliki tugas dan tanggung jawab untuk memberitakan Injil kepada segala makhluk, sesuai amanat agung Yesus Kristus yang terdapat dalam Injil Markus 16:15, yang bunyi, "Pergilah ke seluruh dunia, beritakanlah Injil kepada segala makhluk." Sasaran penginjilan ialah segala makhluk. Makhluk dalam bahasa Yunani-nya ktisis yang berarti segala yang diciptakan oleh Allah, seperti manusia, binatang, tumbuhtumbunan, tanah, air, ikan, dan sebagainya.

(1) Sasaran pertama penginjilan ialah manusia sebagai makhluk ciptaan Allah yang termulia yang telah jatuh ke dalam dosa. Sebagian besar bang-sa Indonesia membutuhkan keselamatan rohani dan jasmani serta kelepasan dari dosa dan setan. Pemuda gereja bertanggung jawab untuk menginjili mereka agar mereka menerima keselamatan dan kelepasan di dalam Yesus Kristus. (2) Sasaran kedua penginjilan adalah pelestarian lingkungan hidup, seperti binatang langka harus dilindungi; hutan atau tumbuh-tumbuhan harus dipelihara, jangan dirusak agar tidak terjadi banjir atau erosi yang dapat menimbulkan bencana atau malapetaka bagi umat manusia; ikan-ikan di laut, danau, dan sungai harus dipelihara, jangan diracuni agar tidak musnah; demikian pula, udara tidak boleh dicemari. Oleh sebab itu, perlu ada penghijauan di pekarangan atau di pinggir jalan kota dan perlu adanya peremajaan hutan lindung agar udara tetap bersih dan sehat. Tanah harus dipelihara dan dijaga kesuburanya agar mendatangkan hasil yang maksimal untuk memenuhi kebutuhan pangan bagi manusia. Itulah peranan yang pertama dari pemuda gereja dalam pembangunan bangsa.

Kedua, pemuda gereja hendaknya berperan aktif dalam mengatasi disintegrasi bangsa demi persatuan dan kesatuan serta keutuhan bangsa, dengan langkah-langkah sebagai berikut: (1) Gejala-gejala yang menimbulkan pertentangan sosial, seperti prasangka-prasangka negatif, etnosentrisme, dan diskriminasi harus dicegah dan dihindari sedapat mungkin. (2) Bentuk-bentuk konflik yang menimbulkan ketegangan atau baik konflik antarindividu maupun antarkolektivitas harus dihindari dan dicegah. (3) Integrasi sosial dan integrasi nasional perlu diupayakan, dengan cara meningkatkan kerukunan antarumat beragama dengan mengadakan kegiatan atau bakti sosial bersama. Yang paling utama ialah bahwa pemuda gereja harus menyatakan kasih kepada sesama warga negara Indonesia, tanpa memandang latar belakang suku, kebudayaan, dan agama serta kepercayaannya, sebagaimana firman Tuhan katakan dalam Kolose 3:14, "Kenakanlah kasih, sebagai pengikat yang mempersatukan dan menyempurnakan." (4) Semangat sumpah pemuda: "satu tanah air, satu bangsa, dan satu bahasa" yang telah diikrarkan oleh pemuda pada tanggal 28 Oktober 1928, perlu dihidupkan kembali di kalangan generasi muda.

Ketiga, dalam pembangunan bangsa, pemuda gereja hendaknya turut serta melakukan upaya pemecahan masalah kemiskinan akibat berbagai krisis yang 
melanda bangsa Indonesia saat ini, dengan langkah-langkah sebagai berikut:

Dengan menerapkan semboyan ora et labora, yaitu berdoa dan bekerja. Kemiskinan seringkali diakibatkan oleh karena manusia tidak bergantung kepada Tuhan dan faktor malas bekerja. Hal malas berdoa dan bekerja sangat ditentang di dalam Alkitab, baik dalam Perjanjian Lama maupun dalam Perjanjian Baru. Beginilah firman TUHAN, "Terkutuklah orang yang mengandalkan manusia, yang mengandalkan kekuatannya sendiri dan yang hatinya menjauh dari TUHAN. Diberkatilah orang yang mengandalkan TUHAN, yang menaruh harapannya pada TUHAN" (Yer. 17:5,7). Mengenai pemalas, firman TUHAN berkata, "Hai pemalas, berapa lama lagi engkau berbaring? Bilakah engkau bangun dari tidurmu? ...maka datanglah kemiskinan dan kekurangan" (Ams. 6:9-11). Dalam 2 Tesalonika 3:10, Rasul Paulus berkata, "...jika seorang tidak mau bekerja, janganlah ia makan." Jadi, untuk mengatasi masalah kemiskinan, seseorang harus bergantung kepada Tuhan dan mau bekerja keras serta tidak boleh malas bekerja. (2) Dengan meningkatkan sumber daya manusia melalui latihan pendidikan keterampilan. Dengan adanya latihan keterampilan ini diharapkan seorang anggota masyarakat mempunyai bekal kemampuan untuk terjun dalam dunia kerja. (3) Dengan menciptakan lapangan kerja atau berwiraswasta. Modal kemampuan yang berupa keterampilan akan menunjang atau memberi bekal bagi generasi muda untuk memperoleh penghasilan yang dapat diterapkan melalui dunia usaha (wiraswasta). Karena bagaimana pun juga, tidak semua orang bisa menjadi pegawai negeri, walaupun telah menyelesaikan studinya di suatu pendidikan formal. Jiwa wiraswasta perlu ditanamkan sejak dini, sehingga kemampuan berusaha ada pada setiap orang. Dengan demikian kita telah turut serta dalam pembangunan bangsa.
Dalam membangun ekonomi nasional bagi kesejahteraan seluruh bangsa Indonesia, pemuda gereja harus turut serta secara aktif dalam memberantas budaya korupsi. Di negara kita, korupsi sudah menjadi penyakit yang kronis, menahun, dan struktural sifatnya. Korupsi dengan segala bentuknya telah menggejala di berbagai kalangan dan bidang kehidupan bangsa kita. Tak dapat dipungkiri, berbagai kasus korupsi turut menyeret bangsa kita ke dalam krisis multidimensi. Setelah empat tahun era reformasi berjalan, kasus korupsi belum juga tuntas ditangani, malahan di antara yang menjadi wakil rakyat dan duduk di pemerintahan era reformasi ini, tak sedikit yang terjerat kasus KKN (korupsi, kolusi, dan nepotisme). Seorang pembaharu besar Cina, Wang An Shih menyebutkan bahwa ada dua sumber korupsi yang selalu terulang, yakni buruknya hukum dan buruknya manusia. Di Indonesia sudah diberlakukan UU Anti Korupsi yang baru, yakni UU No. 3 Tahun 1999, Tentang Pemberantasan Tindak Pidana Korupsi. Tetapi, mengapa korupsi belum juga berhasil diberantas? Hal itu disebabkan oleh faktor moral yang buruk dari manusia yang menjalanankan undangundang tersebut. Betapa pun baiknya undang-undang itu, tetapi apabila moral orang yang menjalankan undang-undang itu rusak dan belum mengalami reformasi, maka undang-undang atau hukum itu tidak akan dapat ditegakkan. Akhirnya, yang terjadi ialah "maling teriak maling." Untuk memberantas budaya korupsi, moral bangsa yang rusak harus direformasi, dan etos kerja yang positif harus diciptakan dengan: (1) meningkatkan disiplin, khususnya disiplin waktu; (2) berlaku jujur, yaitu jujur pada diri sendiri dan tetap bekerja sebagaimana seharusnya, walaupun tidak ada atasan yang melihatnya (Ef. 6:5-7); (3) mengaktualisasikan semangat pengabdian dalam bekerja dengan penuh dedikasi. Kerja jangan hanya dilihat sebagai sarana untuk 
memenuhi kebutuhan ekonomi belaka, tetapi harus dilihat maknanya yang lebih dalam. Dengan bekerja, kita mengaktualisasikan talenta atau kemampuan kita supaya dapat memberi sumbangan untuk kesejahteraan yang berguna bagi semua orang.

\section{Kesimpulan}

Dalam membangun bangsa yang sedang dilanda oleh berbagai krisis, diperlukan peran pemuda gereja yang berkualifikasi, yaitu yang memiliki kualitas spiritual yang tinggi, intelektual yang mampu bersaing, ketahanan dan kualitas moral yang terpuji, dan ideologi yang teruji, dengan mengambil peranan secara aktif dan kreatif dalam memberitakan Injil kepada segala makhluk, berperan aktif dalam mengatasi disintegrasi bangsa demi persatuan dan kesatuan serta keutuhan bangsa, turut serta mengambil bagian dalam upaya pemecahan masalah kemiskinan dengan berdoa dan bekerja keras, meningkatkan sumber daya manusia, dan menciptakan lapangan kerja atau berwiraswasta, dan turut serta secara aktif dalam memberantas budaya korupsi dengan mereformasi moral bangsa yang telah dirusakkan oleh dosa serta menciptakan etos kerja yang positif dengan meningkatkan kedisiplinan, kejujuran dan semangat pengabdian yang berdedikasi tinggi.

\section{Endnotes:}

${ }^{1}$ Topik ini pernah disampaikan dalam Pertemuan/Konsultasi/Pembinaan Pemuda Gereja Se-Provinsi Sulawesi Selatan yang diadakan oleh Departemen Agama Provinsi Sulawesi Selatan di Makassar pada bulan September 2003 di Hotel Istana, Jl. Sungai Saddang No. 96 Makassar.

\section{Kepustakaan}

Alkitab, Jakarta: Lembaga Alkitab Indonesia, 2000.

Bagiyowindi, F.X. Didik, Mengikis Budaya Korupsi, Yogyakarta: Yayasan Pustaka Nusantara, Cet. Pertama, 2003.

Djadi, Jermia, Catatan Khotbah , Ilmu Sosial Dasar, Makassar: Sekolah Tinggi Theologia Jaffray, 1999.

Erari, Karel Phil, Supaya Engkau Membuka Belenggu Kemiskinan, Jakarta: PT BPK Gunung Mulia, 1999.

Octavianus, P., Gereja Memasuki Abad XXI, Malang: Yayasan Persekutuan Pekabaran Injil Indonesia, 1997.

Saririn, Weinita, Iman Kristen dan Pergumulan Kekinian, Jakarta: PT BPK Gunung Mulia, 1996.

-, Gereja Agama-Agama dan Pembangunan Nasional, Jakarta: PT BPK Gunung Mulia, 1998.

Salim, Emil, Lingkungan Hidup dan Pembangunan, Jakarta: Penerbit Mutiara, Cet. Kedua, 1980.

Tanja, Victor I., Spiritualitas, Pluralitas, dan Pembangunan di Indonesia, Jakarta: PT BPK Gunung Mulia, Cet. Kedua, 1996.

Windhu, I. Marsana, Kekuasaan dan Kekerasan Menurut Galtung, Yogyakarta: Penerbit Kanisius, Cet. Pertama, 1992. 